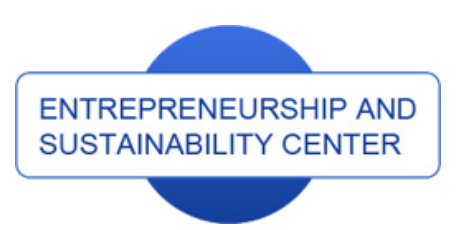

Publisher

http://jssidoi.org/esc/home

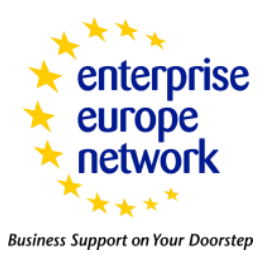

CASPA

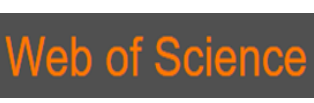

1) Clarivate

Analytics

\title{
ENTREPRENEURIAL ASSESSMENT OF SUSTAINABLE DEVELOPMENT TECHNOLOGIES FOR POWER ENERGY SECTOR*
}

\author{
Andrey Rogalev, Ivan Komarov², Vladimir Kindra ${ }^{3}$, Olga Zlyvko ${ }^{4}$ \\ 1,2 National Research University “Moscow Power Engineering Institute”, Krasnokazarmennaya st., 14, 111250, \\ Moscow, Russian Federation \\ E-mails:1rogalevan@mpei.ru; ${ }^{2}$ komarovii@mpei.ru; ${ }^{3}$ kindravo@mpei.ru; ${ }^{4}$ zlyvkoov@mpei.ru
}

Received 15 June 2018; accepted 18 September 2018; published 30 September 2018

\begin{abstract}
This paper provides a comparative entrepreneurial analysis of modern combined-cycle power generation technologies and future-oriented high-efficiency oxy-fuel combustion cycles with zero emissions. Considering the main criteria for sustainable development, we identify the generation technology that provides the lowest cost of electricity supply and the maximum economic efficiency of investments with equally high environmental indicators. Based on a comprehensive literature review and comparison of the technical and economic parameters of modern and forward-looking generation technologies under different economic conditions, the paper develops and presents the path of increasing the technical level of generation technologies, corresponding to the conditions of sustainable development at each moment of time. Furthermore, the paper analyses the technical and economic characteristics of the combined-cycle technology successfully applied in the world's energy systems and advanced oxy-fuel combustion cycles. In addition, the paper proposes a multifactorial economic-mathematical model that allows to evaluate the performance indicators of any of the considered technologies in accordance with the criteria for sustainable development.
\end{abstract}

Keywords: sustainable development; power industry; greenhouse gas; power generation; economic efficiency; investment

Reference to this paper should be made as follows: Rogalev, A.; Komarov, I.; Kindra, V.; Zlyvko, O. 2018. Entrepreneurial assessment of sustainable development technologies for power energy sector, Enterpreneurship and Sustainability Issues 6(1): 429-445. http://doi.org/10.9770/jesi.2018.6.1(26)

JEL Classifications: O33, Q1; Q4

\section{Introduction}

A high quality of life nowadays and in the future requires a heavy responsibility of society for the environment, moderate exploitation of natural resources at simultaneous social progress and stable economic development

\footnotetext{
* This study was conducted by National Research University "Moscow Power Engineering Institute" and was supported by the Russian Science Foundation under Agreement No. 17-79-20371 dated by July $28^{\text {th }}, 2017$.
} 


\section{The International Journal}

ENTREPRENEURSHIP AND SUSTAINABILITY ISSUES

ISSN 2345-0282 (online) http://jssidoi.org/jesi/ 2018 Volume 6 Number 1 (September) http://doi.org/10.9770/jesi.2018.6.1(26)

(Meadows et al., 1972). The formation of a life space, where all human needs are satisfied at sufficient level at any time without undercutting the basis for development of society in the future, is a complicated, multi-factorial and multi-criterial problem. In order to solve it, it is advisable to decompile the object of research (the society) into sub-objects, which are liable to the less number of factors, and to select the most important of them from the point of influence on the progress of humanity. This paper selects the power generating industry as a sub-object, as well as its technological basis, which is different types of power generating facilities. The technical and economic characteristics of power generating facilities are the link between the economic conditions of power generating industry operations (i.e., fuel price, labour cost, price per tonne of $\mathrm{CO}_{2}$ ) and the resulting parameters that determine the influence of electric power industry condition on the social progress, environment and investment attractiveness (Balitskiy et al., 2014; Zlyvko et al., 2014; Štreimikienè et al., 2016; Strielkowski et al., 2016; Strielkowski et al., 2017a; Strielkowski et al., 2017b; Tvaronavičienė et al., 2017; Strielkowski and Lisin, 2017; Tvaronavičienè 2017; Melas et al., 2017; Tvaronavičienė 2018; Tvaronavičienè et al. 2018).

From the standpoint of sustainable development concept, while planning the development of power industry, one should consider the impact on the state of society. It may be expressed and evaluated as the ratio between the current market price of electric power and the social price level that provides to retain the share of utility fees in the structure of real incomes of households (Kalyugina et al., 2015). The link between the environment and the level of development of electric power industry's technological base can be presented in the units of specific greenhouse gas emissions per $\mathrm{kWh}$ of electric power and converted into the cash equivalent by its multiplication by the price of $\mathrm{CO} 2$ emission allowance. The investment attractiveness is a factor that characterises the possibility of renovation and modernisation of power generating facilities. It can be evaluated in the classic way, through the economic assessment of investment project's efficiency.

The actual choice of electric power generating technologies, each with its technical and economic characteristics, is a way of reaction on changing economic conditions and is a necessary buffer for keeping the development of society sustainable at every moment of time. The forecasting of changes in economic conditions of power generating industry operations and instruments for evaluation and comparison of quantitative assessments of factors of sustainable development are the necessary components for the construction of trajectory of power generating technology shift. This trajectory should ensure the stability and harmonic development of society at the present time and in the foreseeable future. This paper is dedicated to the second approach. While forecasting both prices for greenhouse gas emissions and the natural gas, and the changes of households' incomes level, the authors referred to the present forecasts.

\section{Literature review}

The global warming is one of the most serious challenges to sustainable development of humanity over the last 100 years. Since the early 1900 s, the average air temperature rose by $0.74{ }^{\circ} \mathrm{C}$; moreover, its major increase occurred during the last 35 years. Starting from 1970, each new decade was warmer than the previous by $0.15^{\circ} \mathrm{C}$ (von Deimling, 2006). Figure 1 demonstrates clearly the dynamics of average Earth's surface temperature rising (NASA, 2017). Many scientists agree that the greenhouse effect is the reason of climate change. Lately it is getting worse due to human economic activity. The data announced in the Joint science academies' statement: Global response to climate change (2010) confirm the hypothesis of prevailing impact of anthropogenic factor on the temperature rising. According to it, during the last 250 years, the concentration of carbon dioxide in the atmosphere grew by $95 \mathrm{ppm}$ and now is equal to $375 \mathrm{ppm}$, which is the maximum value in the last 420000 years (NAS, 2005). At the moment, the concentration of carbon dioxide in the atmosphere reached $400 \mathrm{ppm}$ (Curran et al., 2016). The fifth report (2013) by the Intergovernmental Panel on Climate Change revealed the forecast scenarios of temperature anomaly rising by 1.1 to $6.4{ }^{\circ} \mathrm{C}$, depending on the volume of greenhouse gas emission (Climate Change, 2013). 


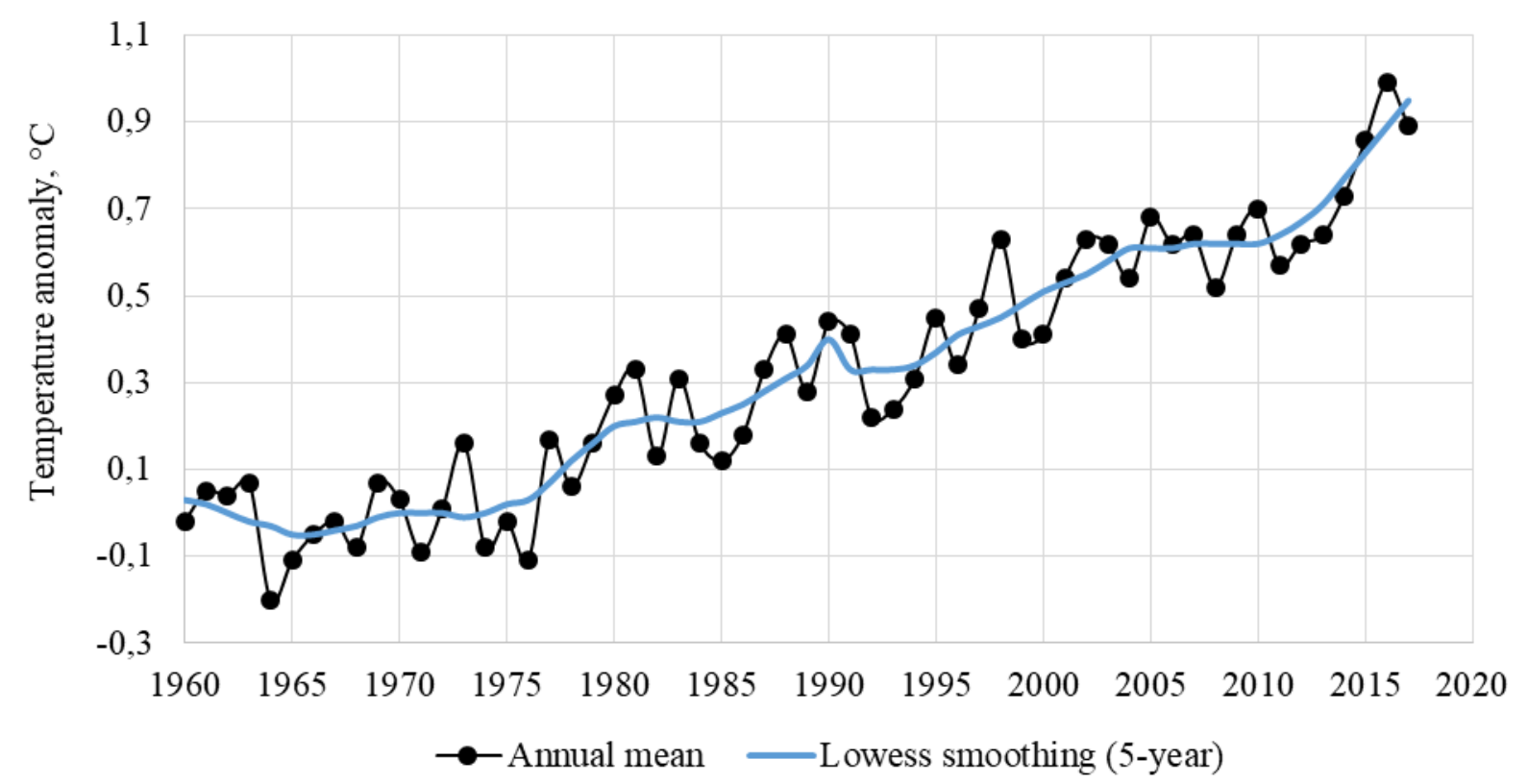

Fig 1. Global temperature index (1960-2017) Source: NASA (2017)

Although the human role in observable temperature anomalies is still actively debated, the worsening of greenhouse effect is a fact. Despite the human contribution in the rise of CO2 concentration, the reduction of greenhouse gas emissions will favour at least the slowing down the global natural processes, if not the termination of warming. In order to implement the practical efforts on fighting the global warming, the Kyoto Protocol was adopted on 11 December 1997, extending the United Nations Framework Convention on Climate Change.

According to terms and conditions of the Kyoto Protocol, the EU entered into commitments to reduce the carbon dioxide emissions by $20 \%$ by 2013 , as compared to the values of 1990 , and maintain the reached target values till 2020. The EU's own plans conditioned by its internal objectives provide the adaptation of its legislation in 2030, reflecting the new target value for the reduction of greenhouse gas emissions by $40 \%$. According to the information by the European Commission, emissions in the EU reduced by $23 \%$ since 1990 till 2016; at that, the GNP grew up by 53 \% (EU ETS) (European Commission, 2018a; European Commission, 2018b). Such high results in improvement of ecological performance of economy were obtained due to stimulation and support of development of power generating units based on renewable energy sources and electric power generating technologies with extremely low carbon emissions.

The operations of CO2 emission allowance (quota) trading at the EU Emission Trade System launched in 2005 are source of funds for instruments of support of new environmentally friendly power generation. The participants of this trade system are the enterprises which technological process is related inseparably to greenhouse gas emissions. Each enterprise emitting into atmosphere shall buy the allowance for greenhouse gas emissions either at the European Energy Exchange in Leipzig, Germany, or at the second auction ring which is the Intercontinental Exchange Futures Europe, London, United Kingdom.

Since 2012 till 2016, the prices at the European Union Allowances (EUA) were stabilised at about $€ 5-7$ per tonne. However, the latest data indicate almost twice price increase at the EUA within the first four months of 2018 up to 
$€ 12.5-14$ per tonne. According to available forecasts, the price per tonne of carbon dioxide emission can reach $€ 25$ by 2030 (Figure 2).

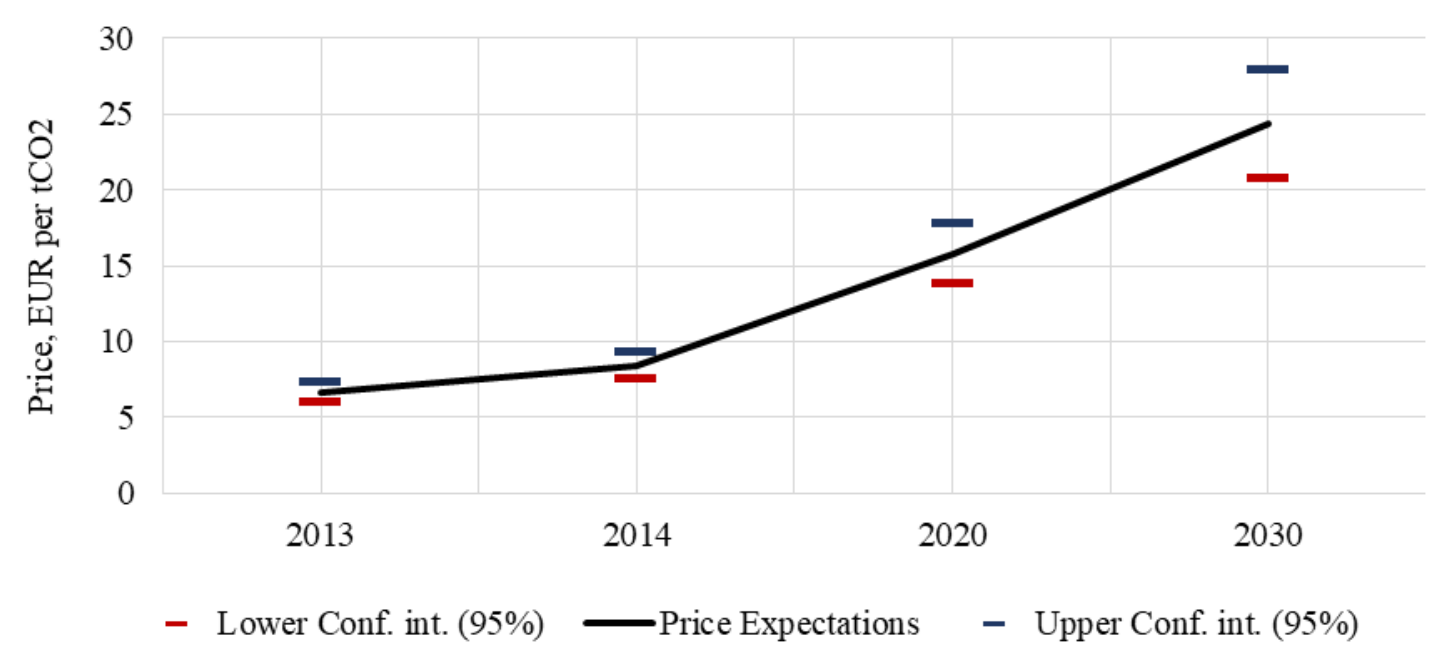

Fig. 2. Forecast of price changes at the EUA Source: European Commission (2015)

Willing to reduce electricity production costs, power generating companies look for new generation technologies with high energy and environmental efficiency (Lisin et al., 2015a). In an increasingly demand the European power and machine-building enterprises and national research institutions actively work on development of new technologies of electric power generation with zero or extremely low greenhouse gas emissions, particularly, those of CO2. Essential reduction of greenhouse gas emissions into atmosphere for traditional technologies is provided by capturing the carbon dioxide from combustion products using special separating membrane units and its further transportation to storage sites, usually such as voids of rocks or the Earth crust formed in a natural way or as a result of human activities in mining the hydrocarbon fuel. However, the implementation of carbon dioxide capture and storage system (CCS) for steam, gas or combined cycle results to significant increase of auxiliary power consumption and decrease of net efficiency by 10-12 \% (Tola et al., 2014). Moreover, the specific capital costs per $\mathrm{kW}$ of installed capacity increase almost twice (up to $\$ 2000-2200$ per $\mathrm{kW}$ ).

The significant increase of efficiency (up to 55-58 \%) at low specific capital costs ( $\$ 700-1000$ per $\mathrm{kW}$ ) is provided by using the oxy-fuel technology of electric power production (Barba et al., 2016). Compared to traditional power generating technologies, the oxy-fuel combustion producing the water steam and carbon dioxide is its main distinguishing feature as well as its main advantage. Such chemical composition of combustion products allows for separation of carbon dioxide and steam by condensation of the latter. It requires the minimum auxiliary power resources and provides the further capture and storage processes. The works on structural and parametric optimisation of cycle arrangements based on various thermodynamic cycles are performed within the framework of this research area. The following cycles of advanced power plants are the best known today: semiclosed oxy-fuel combustion combined cycle (SCOC-CC), NET Power cycle (also called Allam cycle), Graz cycle. The almost total absence of hazardous gas emission is the common characteristic of the above-mentioned cycles. The oxy-fuel technology allows to capture up to $99 \%$ of $\mathrm{CO} 2$ that forms as a result of combustion of carboncontaining fuel in the oxygen. According to existing assessments, the rest of technical and economic parameters of advanced cycles of thermal power plants essentially differ. Cycles are characterised with different levels of efficiency and specific capital costs. The information about the main technical and economic indices for the most 
The International Journal

ENTREPRENEURSHIP AND SUSTAINABILITY ISSUES

ISSN 2345-0282 (online) http://jssidoi.org/jesi/

2018 Volume 6 Number 1 (September)

http://doi.org/10.9770/jesi.2018.6.1(26)

advanced configurations of oxy-fuel cycles is presented in Table 1 (Yang et al., 2012; Allam et al., 2013; Sanz et al., 2005; Advanced, 2002).

Table 1. Technical and economic indices of advanced oxy-fuel power systems

\begin{tabular}{|c|c|c|c|c|c|c|c|}
\hline Cycle & Fuel & $\begin{array}{c}\text { Air } \\
\text { separation } \\
\text { unit type }\end{array}$ & $\begin{array}{c}\text { Initial } \\
\text { tempera-ture, } \\
{ }^{\circ} \mathrm{C} \\
\end{array}$ & $\begin{array}{c}\text { Initial } \\
\text { pressure, } \\
\text { bar }\end{array}$ & Efficiency, \% & $\begin{array}{c}\text { Specific } \\
\text { investment costs, } \\
\$ / k W \\
\end{array}$ & $\begin{array}{c}\text { NET } \\
\text { power, } \\
\text { MW }\end{array}$ \\
\hline SCOC-CC & $\mathrm{CH}_{4}$ & Cryog. & $1,300-1600$ & $60-90$ & $45-50$ & 714 (in 2005) & 400 \\
\hline C Graz cycle & $\mathrm{CH}_{4}$ & Cryog. & 1400 & 180 & $49-54$ & 634.5 (in 2005) & 82.75 \\
\hline $\begin{array}{l}\text { Combined cycle gas } \\
\text { turbine with CCS }\end{array}$ & $\mathrm{CH}_{4}$ & Cryog. & $1400-1600$ & $20-30$ & $44-48$ & $>1000$ & $90-450$ \\
\hline
\end{tabular}

Source: Own results

The SCOC-CC has the least power efficiency as its configuration is the simplest among other oxy-fuel cycles. In fact, this is the Brayton-Rankine combined cycle using oxygen as a fuel oxidiser and the dioxide recirculation. For the temperature of working fluid at the turbine inlet equal to $1300{ }^{\circ} \mathrm{C}$, the net efficiency of electric supply for this cycle does not exceed $45 \%$ (Yang et al., 2012).

The net efficiency of electric supply for NET Power cycle working on the natural gas lays within the range of 55 to $59 \%$. The highest efficiency is reached due to optimisation of parameters of closed cycle of supercritical carbon dioxide. The compression of working fluid in the compressor occurs very close to the phase boundary of carbon dioxide. The carbon dioxide is almost incompressible in this area, and costs for its compression are the minimum. The use of intermediate coolers of compressor also allows to decrease the work for compression. The final increase of working fluid pressure before it is fed into the high-temperature regenerator is occurred in the pump. The high value of the minimum pressure in the cycle (20-30 bar) provides relatively low costs of carbon dioxide storage (Allam et al., 2013).

The idea of development of the Graz cycle belongs to Herbert Jericha who presented his concept to the world research community in 1985. Since then, the cycle was modified many times: the composition of working fluid varied, the low-potential part was separated into an individual circuit, and the recirculating compressor was used in order to withdraw the working fluid right after the heat recovery steam generator. The most effective modification was named the C Graz cycle (Sanz et al., 2005). Among other oxy-fuel cycles, its distinguishing feature is the high content of water steam in the working fluid (up to $79 \%$ ). The intermediate coolers of compressor and relatively low consumption for turbine cooling provide the higher efficiency compared to the SCOC-CC.

Despite the type of used fuel, the greatest net efficiency value on electric supply was observed for the NET Power cycle. For combined cycle units working on the natural gas and coal this parameter is less by 11-12\%. Due to relatively high pressure in the circuit and low number of elements, the unit based on the Allam cycle is rather compact which influences its competitive level of specific capital cost index.

Considering the variety of both existing and advanced power generating technologies providing high environmental performance indices, their comparison at different economic conditions (fuel prices, electricity prices, carbon dioxide prices as the key external economic parameters providing the investment attractiveness of power generating facility) is a matter of interest for the purpose of development of trajectory of power generating technology shift (Lisin et al., 2015a; Lisin et al., 2016). The transition to the new type of power plants will have 
the system impact on the national economy. This effect can be manifested as the change of equilibrium price at the electric power market, the change of the greenhouse gas emission amount, and the change of hydrocarbon fuel consumption. Due to this impact, we shall use the aggregate of criteria considering the influence of parameters of electric power industry on the social and environmental aspects of development of society and on the investment attractiveness of construction of new thermal power plants (Konova et al., 2012; Lisin et al., 2015a; Koelbl et al, 2015).

\section{Model description and the data}

In order to compare different power generating technologies for compliance of criteria of sustainable development at the present and forecast economic conditions, a multi-factorial and multi-criterial economic and mathematical model was developed. The model calculations presume to go through three stages, which essence and sequence are clearly demonstrated at Figure 3.

The first stage of assessment presumes the calculation of ecological efficiency parameters for different power generation technologies. This index depends on three values: fuel type (it determines the composition of combustion products), efficiency of electric production and efficiency of carbon dioxide capture and storage system (if any). Table 2 presents the values of specific emissions of carbon dioxide per $\mathrm{kWh}$ of generated electric energy for modern and advanced electric power generating technologies using the natural gas as a fuel.

According to the data presented in Table 2, the power generating facilities based on the NET power cycle is the most environmentally friendly technology providing the minimum greenhouse gas emissions. Compared to the ordinary combined cycle unit without collection and disposal of $\mathrm{CO} 2$, advanced oxy-fuel power generating units based on the NET power cycle provide the decrease of emissions by $99 \%$. However, oxy-fuel cycles with relatively high emissions (semi-closed oxy-fuel combustion combined cycle) also demonstrate the extremely high efficiency as they decrease emissions by $98.9 \%$. Combined cycle units with CCS demonstrate less significant decrease of $\mathrm{CO} 2$ emissions, $87.5 \%$, which is about $11.4 \%$ worse than the same parameter of oxy-fuel cycles. Screening power generating technologies out with respect to environmental criterion should base on comparison of their indices of decrease of emissions relatively to today's most common types of thermal power plants and regional target values for the decrease of greenhouse gas emissions. The EU plans regarding the decrease of carbon dioxide emissions till 2050 are demonstrated at Figure 4 (EU ETS, 2017).
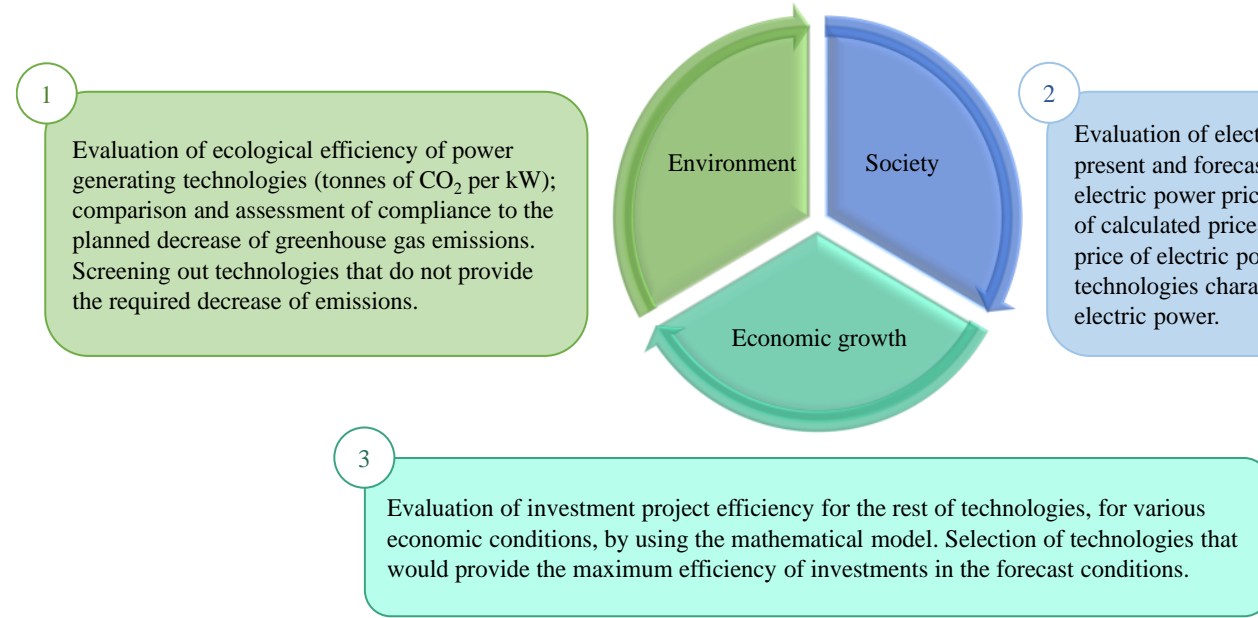

Fig. 3. The stages of calculations for the assessment of parameters of sustainable development while choosing power generating technologies 
The International Journal

ENTREPRENEURSHIP AND SUSTAINABILITY ISSUES

ISSN 2345-0282 (online) http://jssidoi.org/jesi/ 2018 Volume 6 Number 1 (September) http://doi.org/10.9770/jesi.2018.6.1(26)

Source: EU ETS (2017)

Table 2. Specific emissions of $\mathrm{CO} 2$ of different power generating technologies using the natural gas as a fuel

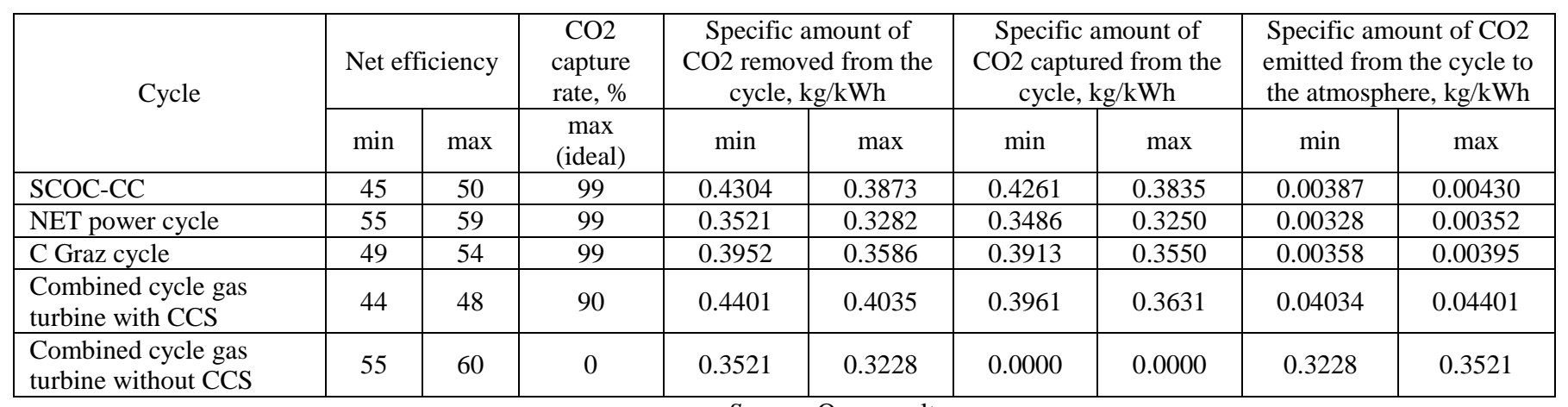

Source: Own results

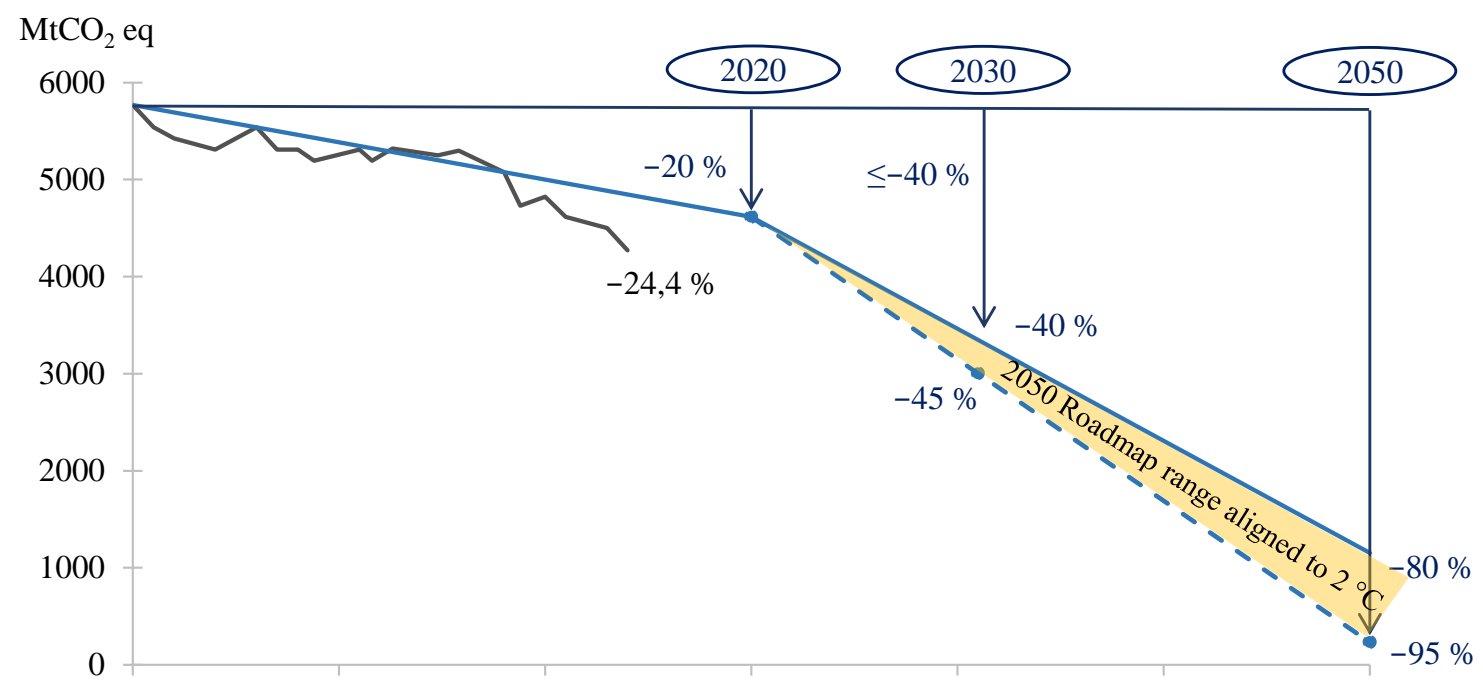

Fig. 4. Planned reduction of $\mathrm{CO} 2$ emissions in the EU to 2050

Source: EU ETS (2017)

According to Figure 4, the emissions of carbon dioxide shall be decreased by $80-95 \%$ by 2050, compared to the level of 1990. So significant decrease of emissions is possible to achieve by improvement of ecological efficiency of equipment in all industries producing emissions (aviation, motor vehicles, steel works, cement plants, etc.). About $25 \%$ of these emissions are produced by power industry. Considering that development and experimental operation of a new technology may take 10 to 15 years while the complete replacement of obsolete generating facilities with new will require decades, one shall develop and then construct thermal power plants, which ecological efficiency indices would significantly exceed today's average level.

Therefore, the criterion of sustainable development that takes into account the influence of electric power industry on the environment can be expressed as follows:

$K_{1}: \Delta E f f_{\text {ecology }} \geq \frac{\Delta V_{\mathrm{CO} 2 i}}{m_{i}} ; \Delta E f f_{\text {ecology }}=\left(1-\frac{E f f_{\text {ecology }}^{\text {new }}}{E f f_{\text {ecology }}^{\text {current }}}\right) \cdot 100 \%$, 
The International Journal

ENTREPRENEURSHIP AND SUSTAINABILITY ISSUES

ISSN 2345-0282 (online) http://jssidoi.org/jesi/

2018 Volume 6 Number 1 (September)

http://doi.org/10.9770/jesi.2018.6.1(26)

where $\Delta E f f_{\text {ecology }}$ represents the growth of ecological efficiency of power generating technology; Eff $f_{\text {ecology }}^{\text {new }}$ and $E f f_{\text {ecology }}^{\text {current }}$ represent the indices of ecological efficiency of new and existing power generating technologies, $\mathrm{kgCO} 2 / \mathrm{kWh} ; \Delta V_{\mathrm{CO}_{2 i}}$ represents required decrease of greenhouse gas emissions to the atmosphere by $i$-th year (the forecast value), $\% ; m_{i}$ represents a coefficient that considers the disbalance between the required rate of improvement of ecological efficiency indices and the real rate of developments; it varies from 0.01 to 1 (the less is the value, the worse is the disbalance).

The second stage is aimed to select technologies that provide the socially acceptable electric power price level for households. According to suggested approach and the concept of sustainable development, the improvement of technology performance in order to respond the challenges should not result to essential decrease of household incomes caused by increased obligatory utility costs in the structure of budget.

Considering the social factor at the limit, we revealed that the invariable value of income share paid by each inhabitant for electric power corresponds to ideal trajectory of power generating technology shift. In order to select technologies to be reviewed at the last stage of assessment, we had to plot the curve of changing the socially acceptable price within the considered period of time. This curve is based on the forecast of change of average household income per capita in different countries (Figure 5) (Global wage, 2013) and on the forecast of change of average electric power price for households (Figure 6) (European Commission, 2016).

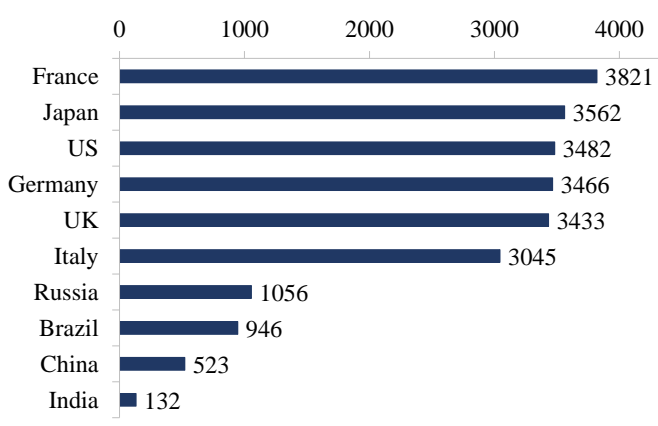

a) in 2011

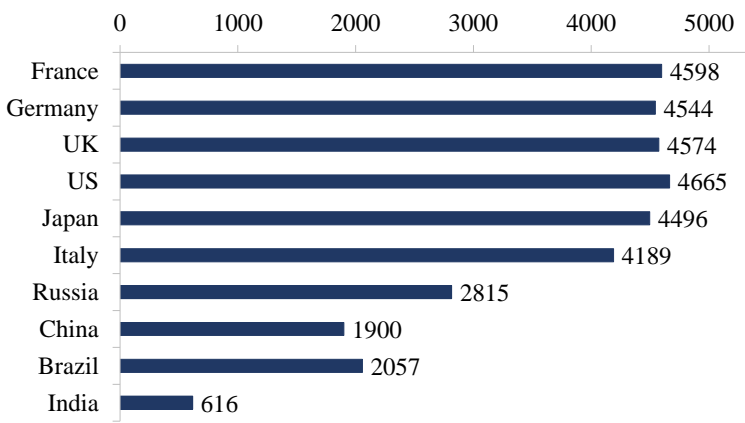

b) in 2030

Fig. 5. Average wage per month (US\$)

Source: European Commission (2016)

We considered Germany as an example. Among other European countries, the electric power consumption index per capita for households of Germany is average and equals to $1,731 \mathrm{kWh}$ per annum. According to the data of 2017, the average net salary after tax in Germany equals to $€ 2302$ per month. Considering the data presented at Figure 6, the income share paid for electric power in Germany is $1 \%$ in average. According to Figure 6, the wages in Germany should increase by $41.7 \%$ by 2030 . Therefore, in order to match the criterion that considers the influence of electric power industry on the social environment, by 2050, the maximum price of electric power for households should not exceed $€ 185$ per MWh. 


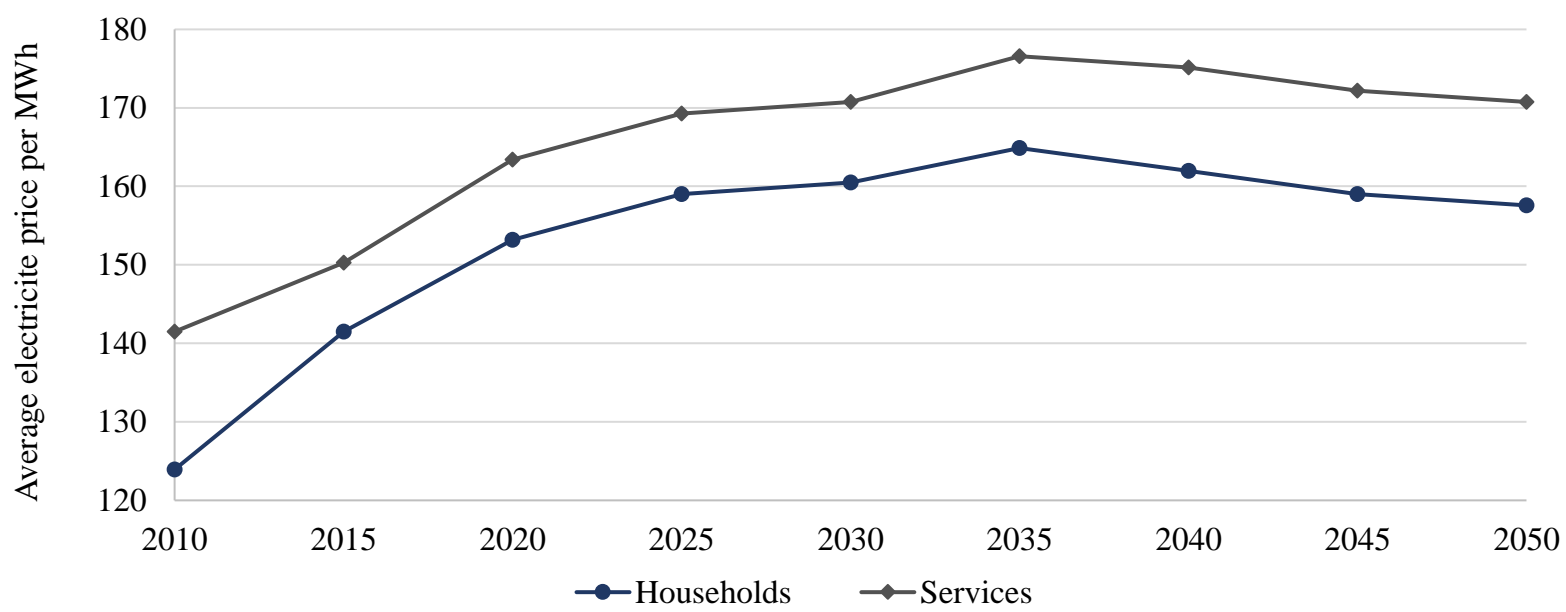

Fig. 6. Forecast of change of average electric power price for various branches of economy in perspective by 2050 Source: European Commission (2016)

In order to select power generating technologies complying to the above-described criterion, it is advisable to proceed from calculated values of cost of electric power supply. At that, the shift to the price of electric power for the purpose of direct comparison of obtained value to the maximum permissible one can be carried out by using the forecast decomposition of electric power cost (Figure 7) (EU ETS, 2017).

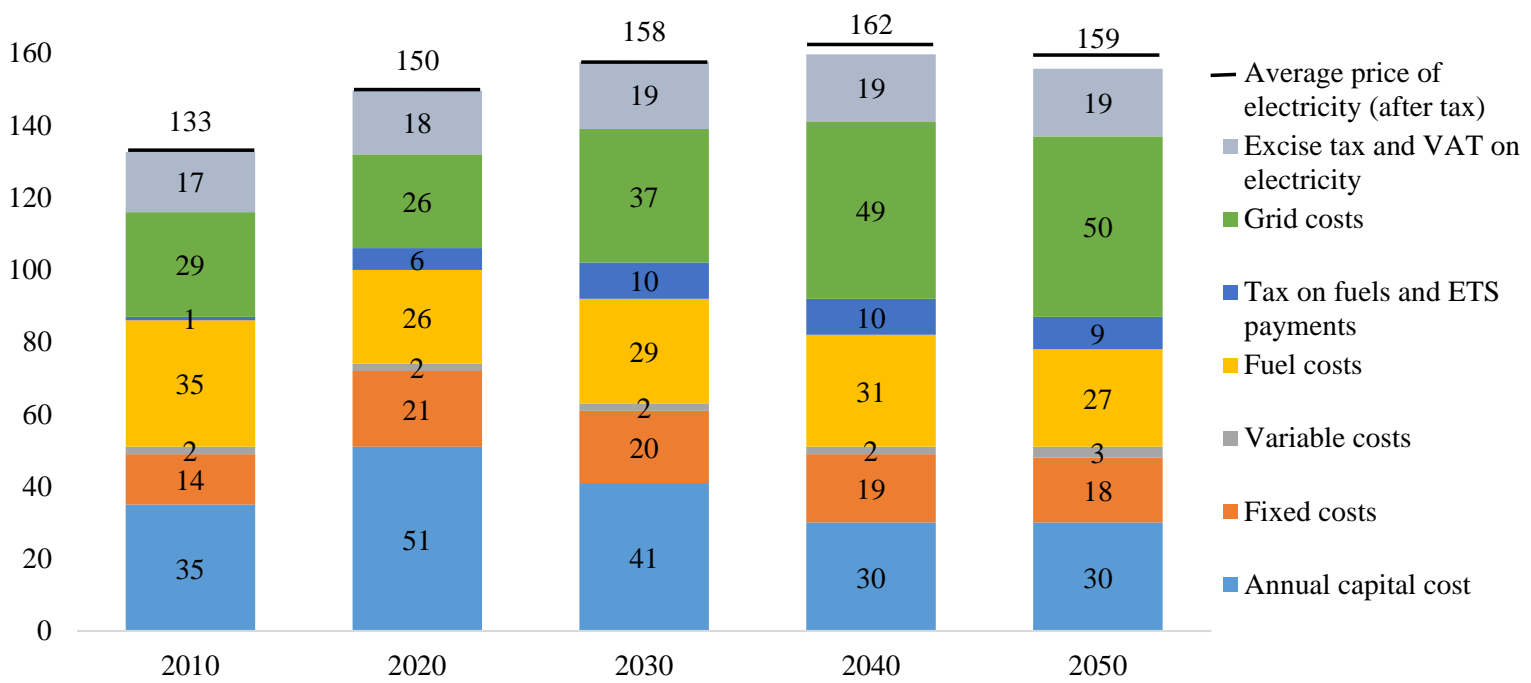

Fig. 7. Forecast decomposition of electric power cost in perspective by 2050 Source: EU ETS (2017)

According to the forecast data presented at Figure 8, the electric power production cost (including taxes) in the structure of electric power price is changing from 86 to $54.7 \%$ from 2010 by 2050.

Proceeding from the above-said, we could formulate the condition of fulfilment of social criterion of sustainable development for the electric power industry as follows:

$$
K_{2}: E P C_{i j} \cdot s_{j}=E C_{i j} \leq E C_{\lim j},
$$


where $E P C_{i j}$ represents the cost of supply of electric power produced by using the $i$-th technology, in $j$-th year's conditions, $€$ per $\mathrm{kWh} ; E C_{i j}$ represents the price of electric power produced by using the $i$-th technology, in $j$-th year's conditions, $€$ per $\mathrm{kWh} ; s_{j}$ represents the share of cost of electric power supply in the structure of its price (for $j$-th year); $E C_{\lim j}$ represents the limit price of electric power at which the share of income paid for utility fees does not increase.

The third stage of assessment includes the calculation of efficiency indices of investment projects of construction of new power generating facilities for the present and forecast economic conditions and subsequent ranking of power generating technologies in descending order of NPV and DPP values. The construction of trajectory of shift to new power generating technologies shall be performed on the basis of selection of various options that would provide the maximum economical efficiency at each moment of time (Lisin et al., 2015b).

The economic and mathematical model is based on the standard equation for calculation of electric power supply cost:

$$
E P C_{i j}=C_{\text {fuel }}+C_{\mathrm{ETS}}+C_{\mathrm{FC}}+C_{\text {wage }}+C_{\mathrm{tax}}
$$

where $C_{\text {fuel }}$ represents specific costs of fuel for thermal power stations, $€$ per $\mathrm{kWh} ; C_{\mathrm{ETS}}$ represents specific costs for the purchase of allowances for $\mathrm{CO} 2$ emissions, $€$ per $\mathrm{kWh} ; C_{\mathrm{FC}}$ represents specific fixed costs (amortisation and repair stock fees), $€$ per $\mathrm{kWh} ; C_{\text {wage }}$ represents specific labour and social insurance costs, $€$ per $\mathrm{kWh} ; C_{\text {tax }}$ represents fuel fees, $€$ per $\mathrm{kWh}$.

The share of fuel costs in the structure of electric power supply costs is about $40-60 \%$. This value depends on the fuel price and efficiency of electric power production:

$$
C_{\text {fuel }}=P_{\text {fuel }} \cdot \frac{0.000611}{\eta_{\mathrm{EP}}}
$$

where $P_{\text {fuel }}$ represents the fuel price, $€$ per boe; $\eta_{\mathrm{EP}}$ represents the efficiency of electric power production. Specific costs for the purchase of allowances for carbon dioxide emissions depend on the allowance price, type of fuel and efficiency. This value for the natural gas is defined as follows:

$$
C_{\mathrm{ETS}}=P_{\mathrm{ETS}} \cdot 0.1934 \cdot\left(1-K_{\mathrm{cap}}\right) \cdot \frac{1}{\eta_{\mathrm{EP}}}
$$

where $P_{\mathrm{ETS}}$ represents the price of allowance for $\mathrm{CO} 2$ emission, $€$ per $\mathrm{kWh} ; K_{\text {cap }}$ represents a coefficient reflecting the rate of captured $\mathrm{CO} 2$ (0 if no CCS system is used).

Labour and social insurance costs is defined as follows:

$$
C_{\text {wage }}=n \cdot W_{\text {av }} \cdot\left(1+\alpha_{\text {social }}\right) \text {, }
$$

where $n$ represents the number of staff of thermal power station (150 employees for $400 \mathrm{MW}$ power unit); $W_{\mathrm{av}}$ represents the average salary in the industry, $€$ per month; $\alpha_{\text {social }}$ represents social insurance fees. 
Fixed costs include repair costs and amortisation. These values are directly proportional to the value of capital costs. Repair costs are defined as follows:

$$
C_{\mathrm{FC}}=I_{\text {specific }} \cdot\left(\beta \cdot \frac{1}{K_{\mathrm{PU}} \cdot \tau_{\text {year }}}+\frac{N_{p p}}{\tau_{\text {expl }}}\right),
$$

where $I_{\text {specific }}$ represents specific capital costs, $€$ per $\mathrm{kW} ; K_{\mathrm{pu}}$ represents a plant-use factor; $\beta$ represents the share of repair costs; $N_{p p}$ represents installed capacity of unit, $\mathrm{kW} ; \tau_{\text {expl }}$ represents a useful life period of thermal power station, years.

Efficiency indices of investment project (NPV and DPP) were evaluated in a classic way on the basis of UNIDO technique provisions.

\section{Results of calculation and analysis}

Each of reviewed power generating technologies matches the target values of existing plans of greenhouse gas emission decrease. According to the data provided above, the oxy-fuel technology allows to decrease the $\mathrm{CO} 2$ emissions by approximately $98.8 \%$ compared to today's widely accepted power generating units based on combined cycle. Modification of combined cycle units by installing the CCS system helps decrease the carboncontaining emissions by $87 \%$. Considering the long terms of development and diffusion of new technologies in the electric power industry (the research, the experimental operation, and the massive renovation of thermal power plants may take 40 years) and significant decrease of carbon dioxide emissions by 2030 (by $20 \%$, see Figure 4), we could assume the value of $m_{i}$ coefficient (equation (1)) equal to 0.25 . Therefore, investment projects of construction of thermal power plants, which could provide the decrease of emission by at least $80 \%$ compared to the present level, should be implemented in the coming decades.

In order to check the reviewed technologies for their compliance to the social criterion of sustainable development, a variants calculations of electric power cost and price for households at the present and forecast economic conditions was carried out. Table 3 presents the basic data for the calculation.

Table 3. The basic data for estimate calculation of cost

\begin{tabular}{|l|c|c|c|c|}
\hline & $\mathbf{2 0 1 7}$ & $\mathbf{2 0 3 0}$ & $\mathbf{2 0 4 0}$ & $\mathbf{2 0 5 0}$ \\
\hline Fuel price, $€$ per boe & 50 & 60 & 70 & 75 \\
\hline Price of CO2 emissions, $€$ per kg of CO2 & 12.8 & 30 & 47 & 90 \\
\hline Labour price, $€$ per employee per annum & 50000 & 50680 & 51187 & 51694 \\
\hline
\end{tabular}

The assumed techno-economic parameters (efficiency, specific $\mathrm{CO} 2$ emissions, and specific capital costs) were presented in Table 1 and Table 2. While calculating the fuel costs, two efficiency values, the minimum and the maximum, were assumed. The minimum efficiency corresponds to the initial level of technology, or its condition before the improvement and modernisation. The maximum efficiency demonstrates the optimistic expectation level, these values are achievable in the future. The maximum value of specific capital costs was assumed. Considering the forecast nature of data and the absence of practically implemented projects of construction of power plants based on oxy-fuel technology, we found it reasonable to assume the overestimated value in order to avoid the possible risks of increase in the cost of thermal power plants.

Figure 8 demonstrates the results of optional calculations of electric power selling price for households, assuming that the electric power was produced using the studied technologies. The transition from the cost of electric power supply, which was determined by estimation of cost items (equation (3)) and their multiplication to the price of 
The International Journal

ENTREPRENEURSHIP AND SUSTAINABILITY ISSUES

ISSN 2345-0282 (online) http://jssidoi.org/jesi/

2018 Volume 6 Number 1 (September)

http://doi.org/10.9770/jesi.2018.6.1(26)

electric power delivered to customers (including the profit of power generating companies), was performed on the basis of forecast rate of electric power supply cost in the structure of overall cost of electric power preparation for consumption. The data were presented at Figure 7.

The curve corresponding to the forecast level of electric power selling price is marked green at Figure 8. Starting from 2030, the price value begins to decrease essentially. As a result, by 2040, only power generating facilities based on NET power cycle will remain profitable when selling the electric power. According to the forecast data, none of reviewed technologies will bring profit by 2050. This result was explained by mutually changing prices of fuel, CO2 emissions, and electric power. The first two parameters, which mostly determine the cost of electric power, will rise by 2050 relatively to the level of 2017: the natural gas price will grow by $50 \%$ and the price of emissions - by $603 \%$. The reason of essential increase of allowance charges for $\mathrm{CO} 2$ emissions are the plans of significant decrease (up to $90 \%$ ) of greenhouse gas emissions by 2050 . However, it is worth mentioning that, due to the high rate of $\mathrm{CO} 2$ capture from combustion products $(99 \%)$, the exponential rise of the EUA prices does not impact essentially on the growth in cost, which is generally determined by the increase of natural gas price. On the other hand, the selling price of electric power will decrease by $22.3 \%$, despite the rise adequate to the growth in cost by 2050 compared to the level by 2030. The disbalance between the price and cost of electric power will result to losses in power generating companies. Table 4 presents the results of calculation of specific revenue gained by selling the electric power at the present and forecast economic conditions.

According to the data presented in Table 4, the present power generating technologies (combined cycle units and those equipped with the CCS) will not bring profit in 2040. Power plants based on the semi-closed oxy-fuel combined cycle and C Graz cycle will be profitable only if these cycles will be highly effective. None of considered technologies will have a positive economic effect by 2050. At that, because of its high efficiency, Allam cycle demonstrates the best performance indices.

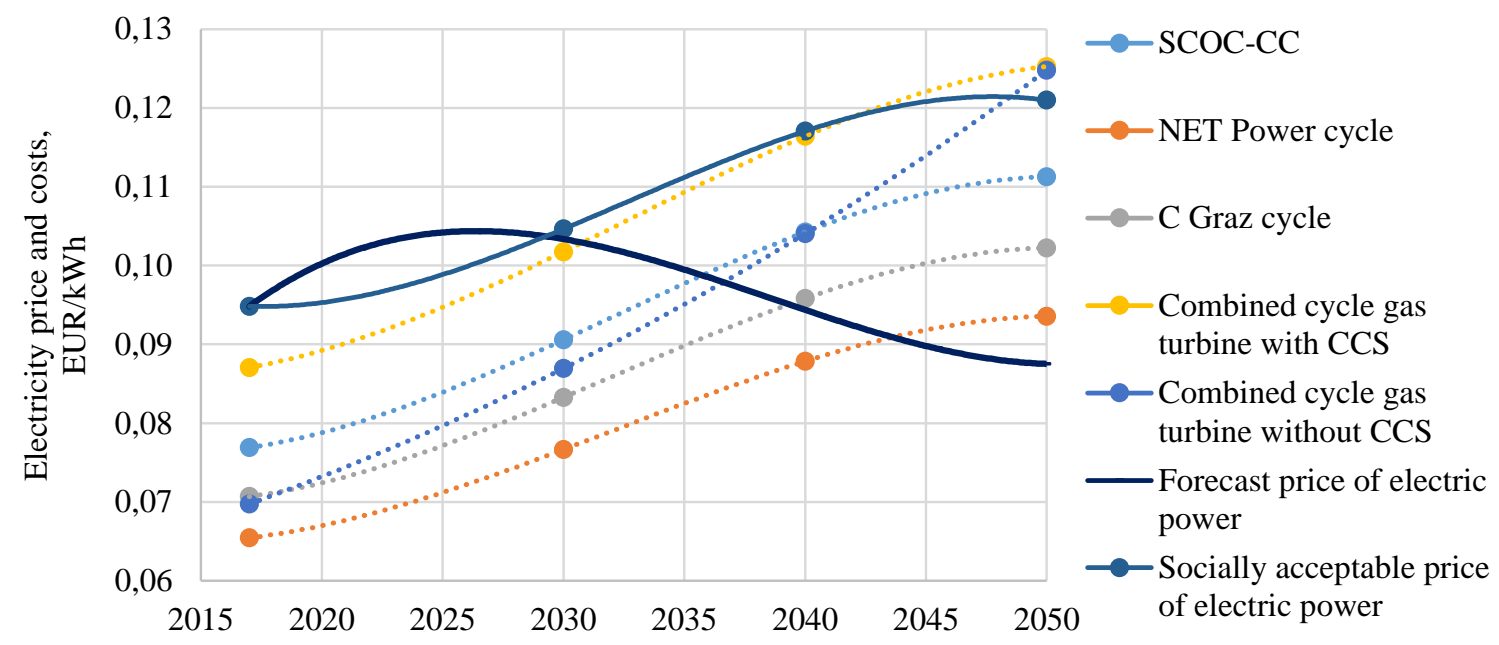

Fig. 8. Change of forecast cost of electric power produced by existing and advanced power generating technologies Source: Own results 
The International Journal

ENTREPRENEURSHIP AND SUSTAINABILITY ISSUES

ISSN 2345-0282 (online) http://jssidoi.org/jesi/

2018 Volume 6 Number 1 (September)

http://doi.org/10.9770/jesi.2018.6.1(26)

Table 4. Specific profit of power generating companies ( $€$ per kWh) at the present and forecast economic conditions (revenue at the minimum efficiency / revenue at the maximum efficiency)

\begin{tabular}{|l|c|c|c|c|}
\hline \multicolumn{1}{|c|}{ Cycle } & $\mathbf{2 0 1 7}$ & $\mathbf{2 0 3 0}$ & $\mathbf{2 0 4 0}$ & $\mathbf{2 0 5 0}$ \\
\hline SCOC-CC & $0.018 / 0.025$ & $0.013 / 0.021$ & $-0.010 / 0.000$ & $-0.024 /-0.014$ \\
\hline NET power cycle & $0.029 / 0.033$ & $0.027 / 0.031$ & $0.007 / 0.012$ & $-0.006 / 0.000$ \\
\hline C Graz cycle & $0.024 / 0.030$ & $0.020 / 0.027$ & $-0.001 / 0.007$ & $-0.015 /-0.006$ \\
\hline Combined cycle gas turbine with CCS & $0.008 / 0.014$ & $0.002 / 0.009$ & $-0.022 /-0.014$ & $-0.038 /-0.029$ \\
\hline Combined cycle gas turbine without CCS & $0.025 / 0.030$ & $0.016 / 0.023$ & $-0.010 /-0.002$ & $-0.037 /-0.028$ \\
\hline
\end{tabular}

Source: Own results

The obtained results do not allow to consider the economic criterion of sustainable development fulfilled starting from 2040 due to the obvious lack of investment attractiveness of electric power generation at assumed forecast conditions. In order to improve it, it is necessary to increase the specific profit of power generating companies by lifting the electric power prices, providing that they do not exceed the socially acceptable values. According to the above-presented estimates, the limit level of electric power price for the customers should not exceed $€ 0.185$ per $\mathrm{kWh}$ in 2050. Using the linear approximation, we could evaluate the limit price for 2040, which is $€ 0.179$ per $\mathrm{kWh}$. Considering that, according to Figure 7, the rate of selling price in the structure of electric power price for households will equal to $57.9 \%$ and $54.7 \%$ in 2040 and 2050 correspondingly, the selling price will equal to the following values: 0.117 (2040) and 0.121 (2050). It is not advisable to set the increased level of price before 2040 as the specific revenue is positive for this period of time. The analysis of profitability of power generating companies was carried out for the new values. Its results are presented in Table 5.

Table 5. Specific revenue of power generating companies ( $€$ per $\mathrm{kWh}$ ) for the new price values (revenue at the minimum efficiency / revenue at the maximum efficiency)

\begin{tabular}{|l|c|c|c|c|}
\hline \multicolumn{1}{|c|}{ Cycle } & $\mathbf{2 0 1 7}$ & $\mathbf{2 0 3 0}$ & $\mathbf{2 0 4 0}$ & $\mathbf{2 0 5 0}$ \\
\hline SCOC-CC & $0.018 / 0.025$ & $0.013 / 0.021$ & $0.013 / 0.022$ & $0.010 / 0.020$ \\
\hline NET power cycle & $0.029 / 0.033$ & $0.027 / 0.031$ & $0.029 / 0.035$ & $0.027 / 0.033$ \\
\hline C Graz cycle & $0.024 / 0.030$ & $0.020 / 0.027$ & $0.021 / 0.029$ & $0.019 / 0.027$ \\
\hline Combined cycle gas turbine with CCS & $0.008 / 0.014$ & $0.002 / 0.009$ & $0.001 / 0.009$ & $-0.004 / 0.005$ \\
\hline Combined cycle gas turbine without CCS & $0.025 / 0.030$ & $0.016 / 0.023$ & $0.013 / 0.021$ & $-0.004 / 0.006$ \\
\hline
\end{tabular}

The results of calculation for the new prices revealed that any oxy-fuel power generating technology will be profitable by 2050 . With that, despite a minor decrease of economic efficiency in time, anyway it will remain sustainably positive on the whole. The existing thermal power plants based on traditional technologies will bring profit only at high values of electric power generation efficiency.

Therefore, the price increase introduced into the model provided the long-term profitability at the 2017 level for the most of companies; at that, it did not result to an extra load for the households in the form of increased share of income spent for the electric power, providing the fulfilment of the social criterion of sustainable development. In order to select the best power generating technology or a group of those after they are checked for matching the ecological and social criteria of sustainable development, it is necessary to perform the final check of investment attractiveness of construction of new power plants and select technologies, the use of which will give the maximum economic efficiency.

This assessment was carried out in accordance with the UNIDO technique. The NPV and DPP indices were the sought values. The maximum efficiency values were assumed for calculations. The estimation of NPV and DPP for a particular year presumed the imaginary start of investment project for construction of a thermal power plant 
The International Journal

ENTREPRENEURSHIP AND SUSTAINABILITY ISSUES

ISSN 2345-0282 (online) http://jssidoi.org/jesi/

2018 Volume 6 Number 1 (September)

http://doi.org/10.9770/jesi.2018.6.1(26)

at the specified moment of time. At that, the external economic parameters were accepted in accordance with the forecast values for this period. While assessing the investment project of 2050, the external economic parameters were evaluated according to the trend formed within the last 10 years. The duration of investment project was accepted equal to 20 years.

The final results of calculation are presented in Table 6 .

The C Graz cycle provides the maximum economic efficiency. Despite the less efficiency of cycle (by $4 \%$ ) compared with NET power cycle, the lower capital costs (by $57.7 \%$ ) provide the fast payback and profitability of investments.

Table 6. Calculated values of NPV and DPP for investment projects of construction of new thermal power plants

\begin{tabular}{|c|c|c|c|c|c|c|c|c|}
\hline \multirow{2}{*}{ Cycle } & \multicolumn{2}{|c|}{2017} & \multicolumn{2}{|c|}{$\mathbf{2 0 3 0}$} & \multicolumn{2}{|c|}{2040} & \multicolumn{2}{|c|}{2050} \\
\hline & NPV & DPP & NPV & DPP & NPV & DPP & NPV & DPP \\
\hline NET power cycle & 74.74 & 12.8 & 6.94 & 19.6 & -31.29 & - & -87.65 & - \\
\hline Combined cycle gas turbine with CCS & -336.26 & - & -372.82 & - & -411.05 & - & -467.41 & - \\
\hline Combined cycle gas turbine without CCS & 74.19 & 12.7 & 15.41 & 18.2 & -22.81 & - & -79.18 & - \\
\hline
\end{tabular}

\section{Conclusions and discussions}

The analysis of data presented in table 6 allows for conclusion regarding the decrease of NPV and increase of DPP for all reviewed power generating technologies in both medium- and long-term perspective. It is caused by decreasing profit of power generating companies due to the forecast disbalance between the electric power price and that of fuel. The increase of the first one to the socially accepted level improved the situation but did not eliminate the disbalance completely. This disbalance resulted to the loss of investment attractiveness of all power generating facilities by 2050 and failure to fulfil the criteria of sustainable development.

Actually, the reason of such results may be the incorrect forecasting of electric power price and its structure as it did not fully consider the dynamics of growth in prices of emissions and fuel. However, such disbalances occur in practice regularly. The market responds to their appearance by increased electric power prices, which may result to essential excess of socially acceptable level and failure to fulfil the social criterion of sustainable development. In order to avoid such situations, the following is required:

- Provision of development of national economy and the increase in labour productivity, and hence, the growth in household incomes, which would be the buffer in case of electric power price rise,

- Development of oxy-fuel power generating technologies and improvement of their efficiency,

- Development of engineering solutions and improvement of technology of manufacturing of power generating equipment, which would provide the decrease in specific capital costs.

In order to solve the scientific problem of selection of power generating technologies providing the sustainable development in different economic conditions, one should design and develop the forecasting tools for electric power market, fuel and energy resource market, and labour market. Also, one should create and develop multifactorial models for evaluation of power equipment costs. These models should provide the possibility of obtaining more accurate estimates of specific capital costs. Some significant results were already obtained in this area. They should be expanded for the oxy-fuel cycle equipment. 
The International Journal

ENTREPRENEURSHIP AND SUSTAINABILITY ISSUES

ISSN 2345-0282 (online) http://jssidoi.org/jesi/

2018 Volume 6 Number 1 (September)

http://doi.org/10.9770/jesi.2018.6.1(26)

The approaches and the model of assessment of oxy-fuel and combined cycle electric power generating technologies from the point of sustainable development provided in this paper soon may be essential in Russia in order to solve the problems of selection of technological base while planning the development of electric power industry in the foreseeable perspective.

\section{Acknowledgements}

This study was conducted by National Research University "Moscow Power Engineering Institute" and was supported by the Russian Science Foundation under Agreement No. 17-79-20371 dated by July $28^{\text {th }}, 2017$.

\section{References}

Allam, R. J.; Palmer, M. R.; Brown, G. W.; Fetvedt, J.; Freed, D.; Nomoto, H.; Jones, C. 2013. High efficiency and low cost of electricity generation from fossil fuels while eliminating atmospheric emissions, including carbon dioxide. Energy Procedia 37: 1135-1149. https://doi.org/10.1016/j.egypro.2013.05.211

Balitskiy, S.; Bilan, Y.; Strielkowski, W. 2014. Energy security and economic growth in the European Union. Journal of Security and Sustainability Issues 4(2):125-132

Barba, F. C.; Sanchez, M.-D. G.; Segui, S. B.; Darabkhani, G. H.; Anthony, E. J. 2016. A technical evaluation, performance analysis and risk assessment of multiple novel oxy-turbine power cycles with complete CO 2 capture. Journal of Cleaner Production 133: 971-985. https://doi.org/10.1016/j.jclepro.2016.05.189

Climate Change 2013: The Physical Science Basis. Cambridge: Cambridge University Press, 2013, p. 1535.

Curran, J. C.; Curran, S. A. 2016. Indications of positive feedback in climate change due to a reduction in Northern Hemisphere biomass uptake of atmospheric carbon dioxide. Weather 71(4): 88-91. https://doi.org/10.1002/wea.2715

EU ETS. 2017. State of the EU ETS Report.

European Commission, 2016. EU Reference Scenario. 2016. Energy, transport and GHG emissions: Trends to 2050. Brussels, p. 221.

European Commission. 2015. Study on the impacts on low carbon actions and investments of the installations falling under the EU Emissions Trading System (EU ETS). Brussels: European Commission, p. 184.

European Commission. 2018a. EU Emissions Trading System (EU ETS). Available from the Internet: https://ec.europa.eu/clima/policies/ets_en

European Commission. 2018b. Strategic Energy Technologies Information System: NER 300: https://setis.ec.europa.eu/NER300

Kalyugina, S.; Strielkowski, W.; Ushvitsky, L.; Astachova, E. 2015. Sustainable and secure development: facet of personal financial issues. Journal of Security and Sustainability Issues 5(2):297-304. https://doi.org/10.9770/jssi.2015.5.2(14)

Koelbl, B. S.; Wood, R.; van den Broek, M. A.; Sanders, M. W. J. L.; Faaij, A. P. C.; van Vuuren, D. P. 2015. Socio-economic impacts of future electricity generation scenarios in Europe: Potential costs and benefits of using $\mathrm{CO} 2$ Capture and Storage (CCS). International Journal of Greenhouse Gas Control 42: 471-484. https://doi.org/10.1016/j.ijggc.2015.08.010 
The International Journal
ENTREPRENEURSHIP AND SUSTAINABILITY ISSUES

ISSN 2345-0282 (online) http://jssidoi.org/jesi/ 2018 Volume 6 Number 1 (September)

http://doi.org/10.9770/jesi.2018.6.1(26)

Konova, O.; Komarov, I.; Lisin, E. 2012. The relevance of power generating capacities based on the combined cycle power plants of high power. Czech Journal of Social Sciences, Business and Economics, 1(1): 101-109. https://doi.org/10.24984/cjssbe.2012.1.1.11

Lisin, E.; Rogalev, A.; Strielkowski, W.; Komarov, I. 2015a. Sustainable modernization of the Russian power utilities industry. Sustainability 7(9): 11378-11400. https://doi.org/10.3390/su70911378

Lisin, E.; Sobolev, A.; Strielkowski, W.; Garanin, I. 2016. Thermal efficiency of cogeneration units with multi-stage reheating for Russian municipal heating systems. Energies 9(4): 269. https://doi.org/10.3390/en9040269

Lisin, E.; Strielkowski, W.; Komarov, I.; Garanin, I. 2015c. Improving the methodology of main power equipment choice for the gas turbine plants. Electronics 19(2): 80-87. https://doi.org/10.7251/ELS1519080L

Meadows, D. H.; Meadows, D. L.; Randers, J.; Behrens, W.W III. The Limits to Growth. New York: Universe Books, 1972 , p. 205.

Melas, V.; Lisin, E.; Tvaronavičienè, M.; Peresadko, G.; Radwański, R. 2017. Energy security and economic development: renewables and the integration of energy systems. Journal of Security and Sustainability Issues 7(1): 133-139. https://doi.org/10.9770/jssi.2017.7.1(11)

NAS. 2005. National Academies of Sciences, Engineering, and Medicine et al. Joint Science Academies' Statement: Global Response to Climate Change.

NASA. 2017 Global Annual Mean Surface Air Temperature Change. https://data.giss.nasa.gov/gistemp/graphs/\#

PWC. 2013. Global wage projections to 2030. London: PWC, p. 14.

Sanz, W.; Jericha, H.; Luckel, F.; Heitmeir, F. 2005. A further step towards a Graz cycle power plant for CO2 capture, Proc. ASME Turbo Expo 2005: Power for Land, Sea, and Air. Reno, NV, USA: ASME, 2005. https://doi.org/10.1115/GT2005-68456

Štreimikienè, D.; Strielkowski, W.; Bilan, Y.; Mikalauskas, I. 2016. Energy dependency and sustainable regional development in the Baltic states: A review. Geographica Pannonica, 20(2):79-87. https://doi.org/10.5937/GeoPan1602079S

Strielkowski, W.; Lisin, E. 2017. Economic Aspects of Innovations in Energy Storage. International Journal of Energy Economics and Policy 7(1): 62-66.

Strielkowski, W.; Lisin, E.; Astachova, E. 2017a. Economic sustainability of energy systems and prices in the EU. Entrepreneurship and Sustainability Issues 4(4): 591-600. https://doi.org/10.9770/jesi.2017.4.4(14)

Strielkowski, W.; Lisin, E.; Tvaronavičienè, M. 2016. Towards energy security: sustainable development of electrical energy storage. Journal of Security and Sustainability Issues 6(2): 43-52. http://dx.doi.org/10.9770/jssi.2016.6.2(4)

Strielkowski, W.; Štreimikienė, D.; Bilan, Y. 2017b. Network charging and residential tariffs: A case of household photovoltaics in the United Kingdom. Renewable and Sustainable Energy Reviews 77:461-473. https://doi.org/10.1016/j.rser.2017.04.029

Tola, V.; Pettinau, A. 2014. Power generation plants with carbon capture and storage: a techno-economic comparison between coal combustion and gasification technologies. Applied Energy 113: 1461-1474. https://doi.org/10.1016/j.apenergy.2013.09.007

Tvaronavičienè, M. 2017. Clusters, innovations and energy efficiency: if relantionship could be traced, Marketing and Management of Innovations 2: 382 - 391 http://doi.org/10.21272/mmi.2017.2-35

Tvaronavičienè, M. 2018. Towards sustainable and secure development: energy efficiency peculiarities in transport sector. Journal of Security and Sustainability Issues 7(4): 719-725. https://doi.org/10.9770/jssi.2018.7.4(9)

Tvaronavičienè, M., Tarkhanova, E., \& Durglishvili, N. 2018. Sustainable economic growth and innovative development of educational systems. Journal of International Studies 11(1): 236-244. https://doi.org/10.14254/2071-8330.2018/11-1/19 
Tvaronavičienè, M.; Nesterova, K.; Kováčik, V. 2017. Energy security and long-term energy efficiency: case of selected counties. Journal of Security and Sustainability Issues 7(2): 349-357. https://doi.org/10.9770/jssi.2017.7.2(14)

von Deimling, T. S.; Held, H.; Ganopolski, A.; Rahmstorf, S. 2006. Climate sensitivity estimated from ensemble simulations of glacial climate. Climate Dynamics 27(2-3): 149-163. https://doi.org/10.1007/s00382-006-0126-8

Yang, H. J.; Kang, D. W.; Ahn, J. H.; Kim, T. S. 2012. Evaluation of design performance of the semi-closed oxy-fuel combustion combined cycle. Journal of Engineering for Gas Turbines and Power 134 (11): 227-238. https://doi.org/10.1115/GT2012-69141

Zlyvko, O.; Lisin, E.; Rogalev, N.; Kurdiukova, G. 2014. Analysis of the concept of industrial technology platform development in Russia and in the EU. International Economics Letters 3(4): 124-138. https://doi.org/10.24984/iel.2014.3.4.2

\section{Andrey ROGALEV}

ORCID: http://orcid.org/0000-0001-7256-0144

Ivan KOMAROV

ORCID: http://orcid.org/0000-0003-3853-8220

\section{Vladimir KINDRA}

ORCID: http://orcid.org/0000-0002-8406-7901

\section{Olga ZLYVKO}

ORCID: http://orcid.org/0000-0003-0554-4026

Register for an ORCID ID:

$\underline{\text { https://orcid.org/register }}$

Copyright (C) 2018 by author(s) and VsI Entrepreneurship and Sustainability Center

This work is licensed under the Creative Commons Attribution International License (CC BY).

http://creativecommons.org/licenses/by/4.0/

(C) (i) Open Access 